\title{
Peningkatan Keaktifan dan Hasil Belajar Siswa melalui Penerapan Strategi Pembelajaran Guided Note Taking Bervariasi pada Mata Pelajaran PKn
}

\author{
Joko Turyanto \\ joko_turyanto@yahoo.com
}

\begin{abstract}
Abstrak
Penelitian ini bertujuan untuk mengetahui penerapan strategi pembelajaran Guided Note Taking bervariasi untuk meningkatkan aktivitas dan hasil belajar pada mata pelajaran PKn. Penelitian ini menggunakan metode kualitatif yang bersifat deskriptif, yaitu mendiskripsikan data dan menginterprestasikan data. Jenis penelitian yang digunakan adalah Penelitian Tindakan Kelas (PTK) yaitu penelitian yang dilakukan oleh peneliti secara langsung. Dari hasil penelitian telah menunjukkan bahwa strategi pembelajaran Guided Note Taking bervariasi dapat meningkatkan meningkatkan: 1) Aktivitas siswa dari kondisi awal yang rata-ratanya hanya $27,33 \%$ menjadi $42,67 \%$ pada siklus I, dan $72,67 \%$ pada siklus II. Terjadi peningkatan yang signifikan dalam ketercapaian aktifitas siswa dari 56,12\% dari siklus I naik menjadi $70,31 \%$ disikklus II. 2) hasil belajar yaitu dari kondisi awal nilai rata-rata kelas 73,04 menjadi 82,14 pada siklus I dan 86,07 pada siklus II. Meningkatnya Aktivitas dan rata-rata nilai hasil belajar di dalam kelas, menunjukkan peningkatan terhadap Aktivitas dan hasil belajar pada mata pelajaran Pendidikan Kewarganegaraan topik usaha pembelaan Negara bagi siswa kelas IXB SMP Negeri 1 Wonosegoro semester 1 tahun pelajaran 2017/2018.
\end{abstract}

Kata kunci: Pembelajaran Guided Note Taking bervariasi, Keaktifan dan Hasil Belajar Siswa

\section{Increasing Student Activity and Learning Outcomes through the Implementation of Guided Note Taking Learning Strategies Varied in Civics Subjects}

\author{
Joko Turyanto \\ joko_turyanto@yahoo.com
}

\begin{abstract}
This study aims to determine the application of Guided Note Taking learning strategies to vary to increase the activity and learning outcomes in Civics subjects. This study is use qualitative methods that are descriptive, namely describing the data and interpreting the data. This type of research is Classroom Action Research (CAR), which is research conducted by researchers directly. From the results of the study have shown that learning strategies Guided Note Taking varies can increase improve: 1) Student activity from the initial conditions which on average only $27.33 \%$ to $42.67 \%$ in the first cycle, and $72.67 \%$ in the second cycle. There was a significant increase in the achievement of student activities from $56.12 \%$ from the first cycle to $70.31 \%$ in the second cycle. 2) learning outcomes namely from the initial conditions the average grade of 73.04 to 82.14 in the first cycle and 86.07 in the second cycle. Increased Activities and the average value of learning outcomes in the classroom, shows an increase in Activities and learning outcomes in the subject of Civics Education, the topic of state defense efforts for IXB grade students of SMP Negeri 1 Wonosegoro in semester 1 of the academic year 2017/2018.

Keywords: Guided Note Taking Learning varies, Student Activity and Learning Outcomes
\end{abstract}




\section{PENDAHULUAN}

Kegiatan pembelajaran yang bermakna adalah proses pembelajaran yang melibatkan keaktifan siswa secara optimal. Di dalam proses kegiatan pembelajaran tersebut terjadi interaksi aktif antara siswa dengan guru maupun siswa dengan siswa. Untuk menciptakan interaksi tersebut, guru memegang peranan yang sangat penting. Guru harus bisa menciptakan suasana yang kondusif, menyenangkan, dan membangkitkan siswa agar mampu berkeaktifan secara optimal. Dalam proses belajar mengajar mata pelajaran Pendidikan Kewarganegaraan dibutuhkan kualifikasi dan kompetensi seorang guru yang memadai, karena Pendidikan Kewarganegaraan (PKn) tidak bersifat statis, akan tetapi selalu dinamis dan mampu menyesuaikan diri dengan perkembangan yang terjadi dalam berbagai aspek kehidupan. Perubahan UndangUndang Dasar Negara Republik Indonesia Tahun 1945 membuat perubahan yang mendasar terhadap kebijakan dalam bidang pendidikan. Muatan kurikulum pasca amandemen UUD 1945, mengalami perubahan isi yang menyangkut aspek hukum, HAM, dan politik. Adanya perubahan tersebut, menuntut siswa untuk lebih berkeaktifan yang maksimal.

Kenyataan yang terjadi, pelajaran PKN dianggap mudah karena hanya membahas hal-hal yang ada dalam kehidupan sehari-hari, seperti gotong royong, musyawarah, tolong menolong, kerja sama, tenggang rasa. Anggapan seperti ini masih terbawa sampai sekarang, bahwa mata pelajaran Pendidikan Kewarganegaraan adalah mudah. Sehingga siswa tidak ada motivasi dan malas dalam mengikuti mata pelajaran Pendidikan Kewarganegaraan. Akibatnya siswa kurang aktif dalam mengikuti pembelajaran. Hal ini akan berdampak pada hasil belajar siswa rendah. Seperti yang terjadi pada saat peneliti melakukan pembelajaran Pendidikan Kewarganegaraan di kelas IXB SMP Negeri 1 Wonosegoro semester 1 tahun pelajaran 2017/2018, ketika menyampaikan materi tentang Usaha Pembelaan Negara, Standar Kompetensi 1. Menampilkan partisipasi dalam usaha pembelaan negara. (Kompetensi Dasar 1.1. Menejelaskan pentingnya usaha pembelaan negara), sebagian besar siswa kurang aktif dalam mengikuti kegiatan belajar mengajar. Hal ini dapat dilihat dari hasil pengamatan dalam kegiatan pembelajaran kondisi awal (pra penelitian). Dari pengamatan proses pembelajaran pada pra penelitian diperoleh data sebagai berikut: 
Dari hasil pengamatan keaktifan belajar siswa kelas IXB di kondisi awal hanya mencapai rata rata7,8 $(27,86 \%)$ yang kurang aktif ada $20,2(72,14 \%)$

Akibat rendahnya keaktifan siswa memiliki dampak terhadap hasil belajar siswa rendah, rata-rata berada dibawah kriteria ketuntasan minimal (KKM). Dari hasil evaluasi diperoleh data bahwa prestasi belajar siswa kelas IXB hanya mencapai rata-rata 73,04 dengan Kriteria Ketuntasan Minimal (KKM) 80.00. Sedangkan ketuntasan belajar secara klasikal hanya mencapai $57,14 \%$, yang seharusnya lebih dari sama dengan $85 \%$. Data hasil belajar siswa yang diperoleh dari kegiatan pembelajaran pada kondisi awal sebagai berikut:

Mencermati hasil nilai siswa yang jauh berada di bawah KKM yang telah ditentukan, peneliti selanjutnya melakukan analisis pembelajaran. Diperkirakan faktor penyebab rendahnya hasil belajar siswa disebabkan oleh rendahnya keaktifan belajar siswa dalam mengikuti pembelajaran Pendidikan Kewarganegaraan.

Dari hasil analisa tersebut peneliti melakukan refleksi yang akhirnya muncullah gagasan untuk mencari sebuah solusi. Upaya penyelesainnya guru harus membangun proses pembelajaran supaya lebih bermakna. Kelas menjadi lebih interaktif, siswa lebih bersifat aktif terlibat dalam kegiatan pembelajaran dan senantiasa meningkatkan sikap berkeaktifan, penalaran logis, dan pemecahan masalah. Langkah yang diambil peneliti di sini adalah menerapkan pola pembelajaran yang menarik dan menyenangkan siswa, sehingga siswa tersebut berpartisipasi aktif dan bisa mengembangkan dirinya secara optimal. Tindakan yang akan dilakukan oleh peneliti adalah membangun proses pembelajaran dengan menerapkan strategi pembelajaran Guided Note Taking bervariasi.

Dalam strategi pembelajaran Guided Note Taking, sebagai guru, menyiapkan suatu bagan atau skema atau yang lain yang dapat membantu siswa dalam membuat catatan-catatan ketika guru menyampaikan materi pelajaran. Ada banyak bentuk atau pola yang dapat dikerjakan untuk strategi ini, salah satunya dan yang palig sederhana adalah mengisi titik-titik (Zaini et al, 2004: 32).

Strategi pembelajaran ini sangat baik untuk menciptakan suasana memacu siswa untuk aktif dalam pembelajaran. Karena siswa akan bertanggung jawab untuk menyelesaikan tugas yang diberikan oleh guru, yaitu melengkapi catatan yang dikosongkan pada bagian-bagian tertentu. Melalui strategi Guided Note Taking, peneliti 
mempredikasi akan mampu menyelesaikan permasalahan yang terjadi di kelas IXB semester 1 tahun pelajaran 2017/2018.

Sebagai langkah operasional, melakukan penelitian dengan mengangkat judul "Peningkatan Keaktifan dan Hasil Belajar melalui Peningkatan Keaktifan dan Hasil Belajar melalui Penerapan Strategi Pembelajaran Guided Note Taking bervariasi pada Mata Pelajaran PKn bagi Siswa Kelas IXB SMP Negeri 1 Wonosegoro Semester 1 Tahun Pelajaran 2017/2018.”.

Berdasarkan latar belakang permasalahan tersebut di atas, maka perumusan masalah dalam penelitian ini adalah: (a) Apakah penggunaan penerapan strategi pembelajaran Guided Note Taking bervariasi dapat meningkatkan aktifitas siswa pada mata pelajaran Pendidikan Kewarganegaraan topik Usaha Pembelaan Negara bagi siswa kelas IXB SMP Negeri 1 Wonosegoro semester 1 tahun pelajaran 2017/2018?.(b) Apakah penggunaan penerapan strategi pembelajaran Guided Note Taking bervariasi dapat meningkatkan hasil belajar siswa pada mata pelajaran Pendidikan Kewarganegaraan topik Usaha Pembelaan Negara bagi siswa kelas IXB SMP Negeri 1 Wonosegoro semester 1 tahun pelajaran 2017/2018?. (c) Apakah penggunaan penerapan strategi pembelajaran Guided Note Taking bervariasi dapat meningkatkan aktifitas dan hasil belajar siswa pada mata pelajaran Pendidikan Kewarganegaraan topik Usaha Pembelaan Negara bagi siswa kelas IXB SMP Negeri 1 Wonosegoro semester 1 tahun pelajaran 2017/2018?.

Sesuai dengan rumusan masalah di atas, maka tujuan umum penelitian ini adalah: (a) untuk meningkatkan keaktifan belajar siswa pada mata pelajaran Pendidikan Kewarganegaraan topik usaha pembelaan negara bagi siswa kelas IXB SMP Negeri 1 Wonosegoro semester 1 tahun pelajaran 2017/2018, (b) umtuk meningkatkan hasil belajar siswa pada mata pelajajaran pendidikan kewarganegaraan topik usaha pembelaan negara bagi siswa kelas IXB SMP Negeri 1 Wonosegoro semester 1 tahun pelajaran 2017/2018. Sedangkan tujuan khusus penelitian ini adalah untuk meningkatkan keaktifan dan hasil belajar melalui strategi pembelajaran Guided Note Taking bervariasi pada mata pelajaran Pendidikan Kewarganegaraaan topik usaha pembelaan negara bagi siswa kelas IXB SMP Negeri 1 Wonosegoro semester 1 tahun pelajaran 2017/2018. Adapun tujuan teoritis penelitian tersebut adalah dengan melalui 
strategi pembelajaran Guided Note Taking bervariasi pada mata pelajaran Pendidikan Kewarganegaraaan topik usaha pembelaan negara akan mempunuyai manfaat Teoritis: Bagi siswa:a. Menghasilkan teori baru dalam pembelajaran PKN melalui strategi Guided Note Taking bervariasi bagi siswa kelas IXB SMPN 1 Wonosegoro .b. Menjadi dasar untuk penelitian selanjutnya pada pembelajaran teks yang sejenis, serta tujuan praktisnya bagi siswa adalah : (1) meningkatkan kemampuan membaca pemahaman (reading comprehensip) siswa, (2) menfasilitasi siswa dengan suasana pembelajaran yang menyenangkan. Sedangkan bagi guru: (1) meningkatkan kemampuan guru dalam memfasilitasi proses pembelajaran siswa di kelas, (2) memberikan alternatif pembelajaran membaca pemahaman (reading comprehensip) dengan cara yang menyenangkan. Bagi perpustakaan sekolah: Menambah daftar buku yang ada di perpustakaan sehingga akan bermanfaat bagi para pembaca khususnya bagi bapak/ibu guru yang akan melaksanakan Penelitian Tindakan Kelas.

Manfaat penelitian ini diharapkan dapat bermanfaat membantu siswa dalam mengatasi rendahnya keaktifan siswa terhadap mata pelajaran Pendidikan Kewarganegaraan dan dapat membantu mendorong guru untuk melakukan penelitian sederhana dalam rangka perbaikan mutu pembelajaran serta bermanfaat bagi Dinas Pendidikan dan Sekolah: Digunakan sebagai bahan pengambilan kebijakan bagi pemutuan pembelajaran di sekolah.

\section{METODE}

Subjek penelitian dalam Penelitian Tindakan Kelas ini adalah siswa kelas IXB SMP Negeri 1 Wonosegoro semester 1 tahun pelajaran 2017/2018 yang berjumlah 30, dengan rincian siswa laki-laki sebanyak 14 dan siswa perempuan sebanyak 16 siswa. Dipilihnya kelas IX B berdasarkan pertimbangan bahwa kelas ini memiliki keaktifan dan hasil belajar yang rendah dibandingkan dengan kelas yang lain.

Sedangkan yang menjadi objek penelitian tindakan kelas ini adalah keaktifan dan hasil belajar pada pembelajaran PKN topik Usaha Pembelaan Negara bagi siswa menyangkut kemampuan mengaktualisasikan ide pada saat siswa mengikuti kegiatan pembelajaran.

Dalam penelitian tindakan kelas ini sumber data yang digunakan terdiri dari dua 
macam yaitu : (1) Sumber data primer

Sumber data ini diperoleh peneliti mulai dari kondisi awal penelitian sampai pelaksanaan tindakan dilakukan. Pada kondisi awal diperoleh data nilai siswa setelah melakukan pembelajaran menyampaikan kompetensi dasar 1.1. Menjelaskan pentingnya usaha bela negara. Pada tindakan siklus I dan II diperoleh nilai hasil belajar siswa setelah peneliti melaksanakan pembelajaran/menyampaikan kompetensi dasar 1.2. Mengidentifikasi bentuk-bentuk usaha pembelaan negara, dan 1.3. Menampilkan peran serta dalam usaha bela negara. (2) Sumber Data Sekunder.

Sumber data sekunder adalah sumber data yang diperoleh peneliti dari hasil pengamatan bersama kolaborator. Yaitu diperoleh data dari hasil observasi dalam proses pembelajaran pada kondisi awal dan proses tindakan pada siklus I dan II.

Prosedur pelaksanaan penelitian tindakan kelas menurut Kurt Lewin dalam Tim Pusat Pendidikan dan Pelatihan Pegawai Kementrian Pendidikan dan Kebudayaan (2016: 44), model Penelitian Tindakan Kelas dapat dilaksanakan melalui 4 tahap yang meliputi: 1. Planning (perencanaan), 2. Acting (Tindakan) 3. Observing (observasi) dan 4. Reflecting (refleksi).

Pelaksanaan kegiatan penelitian tindak kelas ini di laksanakan dengan dua siklus. Masing-masing siklus terdiri dari tahapan perencanaan, tindakan, observasi, dan refleksi, dapat digambarkan sebagai berikut: Adapun rincian dari masing-masing tahapan dapat dijabarkan dengan kegiatan setiap siklusnya .

Tindakan Siklus I dilaksanakan 2 x Pertemuan / 2 x 80 Menit yang terdiri dari (a) Planning pada tahap planning (perencanaan) peneliti menyusun beberapa perencanaan program yang meliputi : Menyusun program pembelajaran, menyusun lembar observasi, menyusun lembar kegiatan siswa, menyusun alat evaluasi dan Mmempersiapkan perangkat lain yang dibutuhkan. (b) Acting pada tahap ini guru menerapkan strategi pembelajaran Guided Note Taking bervariasi. Pada pelaksanaan pembelajaran siklus I, guru menciptakan proses interaksi antara guru dan siswa, seperti membentuk kelompok-kelompok diskusi untuk melakukan presentasi. Masing-masing kelompok diberikan peran yang berbeda untuk menanggapi issu atau permasalahan sebagai bahan adu argumentasi secara bersama-sama dalam kelompok. Selesai diskusi bersama kelompoknya, siswa melakukan presentasi atau adu argumentasi dengan 
kelompok lain. Langkah-langkah kegiatan pembelajaran dilaksanakan sesuai dengan rancangan pembelajaran yang telah disusun sebelumnya (rencana program pengajaran terlampir). (c) Observing pada tahap ini kolaborator melakukan observasi selama kegatan belajar berlangsung. Kolaborator melaksanakan observasi seluruh kegiatan guru dan siswa. Bagaimana cara guru menerapkan strategi pembelajaran Guided Note Taking bervariasi, apakah strategi pembelajaran Guided Note Taking bervariasi mampu menyelesaikan permasalahan yang diangkat dalam penelitian ini?. Bagaimana pula keaktifan belajar siswa dalam mengikuti pembelajaran melalui strategi pembelajaran Guided Note Taking? (Lembar observasi terlampir).

Untuk mengamati keaktifan belajar siswa meliputi aspek-aspek sebagai berikut: 1) Tingkat perhatian siswa terhadap permasalahan; 2) kemampuan mengolah ide; 3) Kemauan untuk menyatakan ide; 4) Kemauan untuk melakukan latihan-latiahan. 5) Ketepatan waktu dalam menyelesaikan tugas. Setelah Akhir pelajaran siswa mengisi angket yang telah disiapkan oleh peneliti dan kolaborator. (d). Reflecting ditahap ini dilakukan evaluasi secara keseluruhan, kemudian kekurangan-kekurangan atau ketidaktercapaian yang terjadi pada siklus I dijadikan sebagai renungan dalam perbaikan kegiatan berikutnya. Perbaikan-perbaikan tersebut dapat berupa metode pembelajaran, media pembelajaran, maupun alat evaluasi yang digunakan.

Tindakan Siklus II sebagaimana juga dilaksanakan di siklus 1 kegiatan siklus 2 juga dilaksanakan 2 x Pertemuan/2 x 80 Menit yang terdiri dari (a) Planning, sedangkan kegiatan yang dilakukan oleh peneliti pada tahap planning (perencanaan) ini sama dengan kegiatan yang dilakukan pada saat perencanaan siklus I, yaitu : Menyusun program pembelajaran, menyusun lembar observasi, menyusun lembar kegiatan siswa, menyusun alat evaluasi, mempersiapkan perangkat lain yang dibutuhkan. (b)Acting ditahap tindakan pada siklus II dilakukan proses pembelajaran dengan menerapkan strategi pembelajaran Guided Note Taking) bervariasi. Dalam pembelajaran ini siswa dibagi dalam kelompok-kelompok yang terdiri dari 5-6 siswa. Jika pada siklus I siswa dalam melakukan presentasi atau adu argumentasi dengan setting tempat duduk mengelompok searah pandangan, sedangkan pada siklus II ini siswa melakukan presentasi atau adu argumentasi dengan setting tempat duduk mengelompok saling berhadapan dengan kelompok lain. Perubahan setting tempat duduk ini dimaksudkan 
agar siswa lebih antusias dan bersaing dalam melakukan presentasi. (Langkah-langkah kegiatan pembelajaran ada pada lampiran). (c) Observing di tahap ini kolaborator melakukan pengamatan selama kegiatan belajar mengajar berlangsung. Baik mengamati keaktifan siswa dalam mengikuti pembelajaran maupun guru dalam menerapkan strategi pembelajaran Guided Note Taking) bervariasi (lembar observasi/pengamatan terlampir).

Untuk mengamati keaktifan belajar siswa meliputi aspek-aspek sebagai berikut: 1) Tingkat perhatian siswa terhadap permasalahan; 2) kemampuan mengolah ide; 3) Kemauan untuk menyatakan ide; 4) Kemauan untuk melakukan latihan-latiahn. 5) Ketepatan waktu dalam menyelesaikan tugas. Setelah Akhir pelajaran siswa mengisi angket yang telah disiapkan oleh peneliti dan kolaborator. (d )Reflecting setelah melakukan evaluasi terhadap pemahaman siswa, maka kekurangan atau ketidaktercapaian pada siklus II akan dijadikan renungan perbaikan dalam kegiatan selanjutnya. Perbaikan-perbaikan itu dapat berupa metode penyampaian, alat bantu (media) yang digunakan, alat evaluasi yang dipakai, atau yang lainnya.

\section{HASIL DAN PEMBAHASAN}

\section{Hasil Penelitian}

\section{Deskripsi Kondisi Awal}

Ketika peneliti melaksanakan kegiatan pembelajaran dengan menyampaikan materi usaha pembelaan negara (Kompetensi Dasar 1.1. Menjelaskan pentingnya usaha pembelaan negara), sekaligus secara partisipan mengamati proses pembelajaran terhadap siswa kelas IXB SMP Negeri 1 Wonosegoro semester 1 tahun pelajaran 2017/2018. Berdasarkan pengamatan tersebut tampak keaktifan siswa dalam mengikuti pembelajaran rendah, dari 30 siswa hanya sebesar 27,33\% yang bisa aktif dalam pembelajaran. Rendahnya keaktifan tersebut sangat berpengaruh terhadap hasil belajar siswa. Akhirnya setelah dilakukan eavaluasi pembelajaran diperoleh hasil nilai siswa dengan rata-rata kelas 73,04. Rata-rata nilai tersebut masih berada di bawah Kriteria Ketuntasan Minimal (KKM) yaitu 80. Berikut hasil pengamatan hasil pengamatan Keaktifan Belajar Kelas IXB Siswa pada Kondisi Awal 
Tabel 1. Hasil Pengamatan Keaktifan Belajar Kelas IXB pada Kondisi Awal

\begin{tabular}{|c|c|c|c|}
\hline \multirow[b]{2}{*}{ No } & \multirow{2}{*}{$\begin{array}{c}\text { Indikator ketercapaian keaktifan } \\
\text { belajar siswa }\end{array}$} & \multicolumn{2}{|c|}{ Respon Siswa } \\
\hline & & $\mathrm{Ya}$ & Tidak \\
\hline 1 & $\begin{array}{lll}\text { Perhatian siswa terhadap } \\
\text { permasalahan }\end{array}$ & 10 siswa $(33,33 \%)$ & 20 siswa $(66,67 \%)$ \\
\hline 2 & Kemampuan mengolah ide & 9 siswa $(30,00 \%)$. & 21 siswa $(70 \%)$ \\
\hline 3 & Kemampuan untuk menyatakan ide & 5 siswa $(16,67 \%)$ & 25 siswa $(83,33 \%)$ \\
\hline 4 & $\begin{array}{l}\text { Kemampuan untuk melakukan } \\
\text { latihan-latihan }\end{array}$ & 8 siswa $(26,67 \%)$ & 22 siswa $(73,33 \%)$ \\
\hline 5 & $\begin{array}{l}\text { Ketepatan waktu dalam } \\
\text { menyelesaikan tugas }\end{array}$ & 9 siswa $(30,00 \%)$ & 21 siswa $(70 \%)$ \\
\hline & RATA-RATA & $8,2(27,33 \%)$ & $21,8(72,67 \%)$ \\
\hline
\end{tabular}

Tabel 2. Hasil Belajar Siswa Kelas IXB pada Kondisi Awal

\begin{tabular}{|c|c|c|c|c|}
\hline No & Rentang Nilai & Jumlah Siswa & Prosentase & Kategori \\
\hline 1 & $90-100$ & 0 & 0 & Tinggi \\
\hline 2 & $80-90$ & 14 & 46,66 & Sedang \\
\hline 3 & $<80$ & 16 & 53,34 & Rendah \\
\hline & Jumlah & 30 & 100 & \\
\hline \multicolumn{4}{|c|}{ Nilai Tertinggi } & 85 \\
\hline \multicolumn{4}{|c|}{ Nilai Terendah } & 40 \\
\hline \multicolumn{4}{|c|}{ Rata-rata } & 73,04 \\
\hline
\end{tabular}

Data tabel kondisi awal di atas menunjukan bahwa akibat rendahnya keaktifan siswa memiliki dampak terhadap hasil belajar siswa rendah, rata-rata berada dibawah kriteria ketuntasan minimal (KKM).

Dari hasil evaluasi diperoleh data bahwa prestasi belajar siswa kelas IXB hanya mencapai rata-rata 73,04 dengan Kriteria Ketuntasan Minimal (KKM) 80.00. Sedangkan ketuntasan belajar secara klasikal hanya mencapai $57,14 \%$, yang seharusnya lebih dari sama dengan $85 \%$. 


\section{Siklus 1}

Secara garis besar diperoleh catatan selama pengamatan dalam proses pembelajaran dengan strategi pembelajaran Guided Note Taking bervariasi sebagai berikut: (a).Siswa tampak ambisi melakukan presentasi di depan kelas. Siswa kelihatan berkeinginan tinggi menjadi kelompok yang terbaik. (b).Kegiatan belajar mengajar tampak hidup, siswa berpartisipasi aktif, interaksi sosial terjalin dengan baik, kehidupan demokratis tampak melakukan diskusi kelompok dan melakukan presentasi.(c).Hasil pengamatan selama proses pembelajaran siklus I, peneliti bersama kolaborator diperoleh data seperti berikut:

(1) Tingkat perhatian siswa terhadap permasalahan sebesar 53,33\%.

(2) Kemampuan mengolah ide sebesar $36,66 \%$.

(3) Kemauan untuk menyatakan ide 43,33\%.

(4) Kemauan untuk melakukan latihan-latihan $30 \%$.

(5) Ketepatan waktu dalam menyelesaikan tugas 50\%

Tabel 4. Hasil Pengamatan Keaktifan Siswa Tindakan Siklus I

\begin{tabular}{|c|c|c|c|}
\hline \multirow{2}{*}{ No } & \multirow{2}{*}{$\begin{array}{c}\text { Indikator Ketercapaian Keaktifan dalam } \\
\text { Pembelajaran Guided Note Taking } \\
\text { Bervariasi. }\end{array}$} & \multicolumn{2}{|c|}{ Banyaknya Siswa yang Merespon } \\
\hline & & $\mathrm{Ya}$ & Tidak \\
\hline 1 & $\begin{array}{l}\text { Tingkat perhatian siswa terhadap } \\
\text { permasalahan }\end{array}$ & $16(53,33 \%)$ & $14(46,67 \%)$ \\
\hline 2 & Kemampuan mengolah ide & $11(36,66 \%)$ & $19(63,33 \%)$ \\
\hline 3 & Kemauan untuk menyatakan ide & $13(43,33 \%)$ & $17(56,67 \%)$ \\
\hline 4 & $\begin{array}{l}\text { Kemauan untuk melakukan latihan- } \\
\text { latihan }\end{array}$ & $9(30 \%)$ & $21(70 \%)$ \\
\hline 5 & $\begin{array}{l}\text { Ketepatan waktu dalam menyelesaikan } \\
\text { tugas }\end{array}$ & $15(50 \%)$ & $15(50 \%)$ \\
\hline & RATA-RATA & $\begin{array}{c}12,80 \\
(42,67 \%)\end{array}$ & $17,20(57,33 \%)$ \\
\hline
\end{tabular}

Penerapan model pembelajaran Guided Note Taking bervariasi pada siklus I dapat diambil kesimpulan bahwa rata-rata keaktifan siswa dalam menerima pelajaran 
dapat mencapai 42,67\%. Ada peningkatan keaktifan siswa sebesar 56,12\% dari kondisi awal yang rata-rata hanya $27,33 \%$. Meningkatnya keaktifan siswa ini menunjukkan kenaikan yang sangat signifikan.

Setelah selesai tindakan pada siklus I kemudian dilaksanakan evaluasi belajar untuk mengetahui sejauh mana siswa menguasai kompetensi yang telah dibelajarkan. Melalui evaluasi tersebut akan diperoleh data kuantitatif yang berupan nilai hasil belajar siswa. Hasil belajar pada siklus ini, kemudian dianalisis untuk mengetahui ketuntasan belajar sesuai dengan criteria ketuntasan minimal. Pada siklus I ini diperoleh data sebagai berikut:

Tabel 5. Analisis Hasil Belajar Siswa Kelas IXB pada Siklus I

\begin{tabular}{|c|c|c|c|c|}
\hline No & Rentang Nilai & $\begin{array}{c}\text { Jumlah } \\
\text { Siswa }\end{array}$ & Prosentase & Kategori \\
\hline 1 & $90-100$ & 0 & 0 & Tinggi \\
\hline 2 & $8-90$ & 25 & 89,29 & Sedang \\
\hline 3 & $<805$ & 21 & 10,71 & Rendah \\
\hline \multicolumn{3}{|c|}{ Jumlah } & 100 & 90 \\
\hline \multicolumn{3}{|c|}{ Nilai Terendah } \\
\hline \multicolumn{3}{|c|}{ Rata-rata } \\
\hline
\end{tabular}

Dari data tersebut diperoleh nilai hasil belajar siswa dengan rata-rata kelas 82,14. Rata-rata tersebut sudah melampaui Kriteria Ketuntasan Minimal (KKM) yang harus dicapai pada kompetensi dasar adalah 80.00. Dapat dikatakan ada peningkatan hasil belajar jika dibandingkan dengan kondisi awal yang hanya rata-rata nilai hasil belajar 73,04. Sedangkan ketuntasan belajar secara klasikal dari perolehan data tersebut di atas mencapai 89,29\%. Dengan dicapainya ketuntasan belajar 89,29\%, maka secara klasikal dinyatakan tuntas belajar.

Dari pembahasan tersebut di atas, maka kegiatan pada siklus I ini dapat diambil kesimpulan bahwa: (a) Ada peningkatan keaktifan siswa kelas IXB sebesar 56,12\% dari kondisi awal 27,33\% menjadi 42,67\%. Peningkatan yang mencapai lebih dari 50\% tersebut menunjukkan kenaikan yang signifikan.(b)Ada peningkatan hasil belajar siswa 
sebesar $12,45 \%$, dari kondisi awal rata-rata nilai hasil belajar 73,04 menjadi 82,14 pada siklius I. Peningkatan nilai rata-rata kelas tersebut dapat meningkatkan ketuntasan belajar secara klasikal.

Perbandingan keaktifan dan hasil belajar siswa kelas IXB SMP Negeri 1 Wonosegoro semester 1 Tahun pelajaran 2017/2018 pada kondisi awal dengan siklus I dapat disusun dalam table sebagai berikut:

Tabel 6. Perbandingan Keaktifan dan Hasil Belajar Siswa pada Kondisi Awal dengan Siklus I

\begin{tabular}{|c|c|c|c|c|}
\hline $\mathrm{NO}$ & Ranah & $\begin{array}{c}\text { Rata-rata } \\
\text { Kondisi Awal }\end{array}$ & $\begin{array}{l}\text { Rata-rata } \\
\text { Siklus I }\end{array}$ & Keterangan \\
\hline 1 & $\begin{array}{ll}\text { Respon } & \text { Keaktifan } \\
\text { Siswa } & \end{array}$ & $27,33 \%$ & $42,67 \%$ & \multirow{2}{*}{$\begin{array}{l}\text { Keaktifan belajar } \\
\text { meningkat } 56,12 \%, \\
\text { hasil belajar siswa meningkat } \\
12,45 \% .(82,14-73,04 \\
/ 73,04)\end{array}$} \\
\hline 2 & $\begin{array}{l}\text { Nilai Hasil Belajar } \\
\text { Siswa }\end{array}$ & 73,04 & 82,14 & \\
\hline
\end{tabular}

Pembahasan Siklus II

Pada saat tindakan siklus II ini dilaksanakan, siswa semakin tertarik pada strategi pembelajaran Guided Note Taking bervariasi. Ketertarikan siswa ini dalam pengamatan peneliti terletak pada modifikasi strategi pembelajaran Guided Note Taking yang sudah diterapkan pada siklus I. Pada siklus I presentasi dilaksanakan dengan seting tempat duduk searah, sedangkan pada siklus II presentasi dilaksanakan dengan setting tempat duduk saling berhadap-hadapan. Dengan teknik semacam ini siswa merasa tertantang untuk melakukan eksplorasi melalui Tanya jawab. Oleh karena itu siswa berupaya sungguh-sungguh untuk mampu menjadi yang terbaik di antara kelompok-kelompok lain.

Kondisi yang demikian ini membuat pembelajaran semakin efektif, sebab siswa semakin antusias dalam menanggapi masalah. Interaksi sosial antara siswa dengan guru, siswa dengan siswa dapat tercipta dengan baik. Proses pembelajaran berpusat pada siswa, dan tidak searah. Siswa dapat mengembangkan potensinya secara optimal. Dari pengamatan peneliti dengan kolaborator dapat diperoleh hasil data 
observasi atau pengamatan terhadap aktivitas siswa selama proses pembelajaran. Dari hasil pengamatan selama proses pembelajaran siklus II, peneliti bersama kolaborator memperoleh data seperti berikut: 1)Tingkat perhatian siswa terhadap permasalahan sebesar 83,33\%. 2) Kemampuan mengolah ide sebesar 66,67\%. 3) Kemauan untuk menyatakan ide 60,00\%. 4)Kemauan untuk melakukan latihan-latihan 73,33\%. 5) Ketepatan waktu dalam menyelesaikan tugas $80 \%$. Rata rata ketercapaian keaktifan siswa mencapai $72,67 \%$.

Berdasarkan data pengamatan yang diperoleh peneliti dan kolabolator tersebut di atas, maka hasil observasi atau pengamatan keaktifan siswa pada siklus II dapat disusun secara rinci dalam tabel sebagai berikut:

Tabel 7. Hasil Pengamatan Keaktifan Siswa pada Siklus II

\begin{tabular}{|c|c|c|c|}
\hline \multirow{2}{*}{ No } & \multirow{2}{*}{$\begin{array}{l}\text { Indikator Ketercapaian Keaktifan dalam } \\
\text { Pembelajaran Guided Note Taking } \\
\text { bervariasi. }\end{array}$} & \multicolumn{2}{|c|}{ Banyaknya Siswa yang Merespon } \\
\hline & & $\mathrm{Ya}$ & Tidak \\
\hline 1 & Tingkat perhatian siswa terhadap & $25(83,33 \%)$ & $5(16,67 \%)$ \\
\hline 2 & permasalahan Kemampuan mengolah ide & $20(66,67 \%)$ & $10(33,33 \%)$ \\
\hline 3 & Kemauan untuk menyatakan ide & $18(60,00 \%)$ & $12(40,00 \%)$ \\
\hline 4 & Kemauan untuk melakukan latihan-latihan & $22(73,33 \%)$ & $8(26,67 \%)$ \\
\hline 5 & $\begin{array}{l}\text { Ketepatan waktu dalam menyelesaikan } \\
\text { tugas }\end{array}$ & $24(80,00 \%)$ & $6(20 \%)$ \\
\hline & RATA-RATA & $\begin{array}{c}21.80 \\
(72,67 \%)\end{array}$ & $8,20(27,33 \%)$ \\
\hline
\end{tabular}

Data pengamatan tersebut menunjukkan adanya peningkatan keaktifan siswa dari siklus I ke siklus II. Keaktifan siswa pada siklus I, respon siswa rata-rata 42,67\% atau sebanyak 12,8 orang dari jumlah siswa 30 siswa. Pada siklus II keaktifan siswa menunjukkan angka rata-rata $72,67 \%$ atau sebanyak 21,80 dari 30 orang siswa. Ada peningkatan keaktifan belajar siswa sebesar dari 56,12\% di siklus I meningkat menjadi $70,31 \%$ di siklus II.

Setelah selesai pembelajaran pada siklus II kemudian dilaksanakan penilaian untuk mengetahui hasil belajar siswa. Hasil belajar pada siklus II ini setelah dianalisa 
diperoleh data sebagai berikut:

Tabel 8. Analisis Hasil Belajar Siswa Kelas IXB pada Siklus II

\begin{tabular}{|c|c|c|c|c|}
\hline No & Rentang Nilai & Jumlah Siswa & Prosentase & Kategor \\
\hline 1 & $90-100$ & 3 & 10,71 & Tinggi \\
\hline 2 & $80-90$ & 25 & 89,29 & Sedang \\
\hline 3 & $<80$ & 0 & 0 & Rendah \\
\hline & Jumlah & 28 & 100 & \\
\hline \multicolumn{4}{|c|}{ Nilai Tertinggi } & 95 \\
\hline \multicolumn{4}{|c|}{ Nilai Terendah } & 80 \\
\hline \multicolumn{4}{|c|}{ Rata-rata } & 86,07 \\
\hline
\end{tabular}

Dari data tersebut diperoleh nilai hasil belajar siswa dengan rata-rata kelas 86,07. Terdapat peningkatan nilai hasil belajar dari siklus I dengan rata-rata nilai hasil belajar 82,14 menjadi 86,07 pada siklus II. Ada kenaikan sebesar 4,78\%. Sedangkan rata-rata ketuntasan belajar secara klasikal meningkat menjadi tinggi, dari 89,29\% pada siklus I menjadi 100\% pada siklus II. Dengan dicapainya ketuntasan belajar 100\%, maka secara klasikal dinyatakan tuntas belajar.

Dari pembahasan siklus II tersebut dapat disimpulkan bahwa:

Ada peningkatan rata-rata keaktifan belajar siswa kelas IXB dari siklus I sebesar 42,67 $\%$ menjadi $72,67 \%$ pada siklus II. Sehingga peningkatan keaktifan tetersebut mencapai 70,31\%. Adapun peningkatan hasil belajar siswa sebesar 4,78\%, dari kondisi awal ratarata nilai hasil belajar 82,14 menjadi 86,07 pada siklius II. Prosentase ketuntasan belajar klasikal meningkat tinggi menjadi $100 \%$.

\section{Pembahasan Antar Siklus}

Perbandingan keaktifan dan hasil belajar siswa kelas IXB SMP Negeri 1 Wonosegoro semester 1 Tahun pelajaran 2017/2018 pada siklus I dengan siklus II dapat disusun dalam table sebagai berikut: 
Tabel 9. Perbandingan Keaktifan dan Hasil Belajar Siswa pada Siklus I dengan Siklus II

\begin{tabular}{|c|l|c|c|c|c|}
\hline NO & \multicolumn{1}{|c|}{ Ranah } & $\begin{array}{c}\text { Rata-rata } \\
\text { Pra siklus }\end{array}$ & $\begin{array}{c}\text { Rata-rata } \\
\text { Siklus I }\end{array}$ & $\begin{array}{c}\text { Rata-rata } \\
\text { Siklus II }\end{array}$ & Keterangan \\
\hline 1 & $\begin{array}{l}\text { Respon Keaktifan } \\
\text { Siswa } \\
27,33 \%\end{array}$ & $42,67 \%$ & $72,67 \%$ & & \\
2 & $\begin{array}{l}\text { Peningkatan Keaktifan } \\
\text { Belajar Siswa }\end{array}$ & $56,12 \%$ & $70,31 \%$ & \\
\hline
\end{tabular}

pembelajaran yang masih konvensional, yaitu dengan metode ceramah. Selama proses pembelajaran berlangsung, siswa hanya pasif, tidak terjadi interaksi timbal balik antara guru dengan siswa maupun siswa dengan siswa. Sehingga tidak ada aktivitas siswa selama pembelajaran, siswa hanya mendengarkan ceramah guru dan kadang-kadang diselingi mencatat.

Kondisi seperti ini menyebabkan siswa tidak ada motivasi untuk aktif dalam mengikuti pembelajaran. Setelah dilakukan pengamatan, keaktifan siswa hanya rata-rata 27,33\%. Dampak terhadap hasil belajar siswa adalah rendah. Setelah diadakan penilaian akhir pelajaran, hasil belajar siswa hanya mencapai rata-rata kelas sebesar 73,04. Nilai tersebut berada di bawah Kriteria Ketuntasan Minimal (KKM) yang telah ditentukan 80,00. Berarti dapat dikatakan bahwa hasil belajar siswa rendah.

Rendahnya hasil belajar, menjadi permasalahan yang harus diselesaikan oleh guru. Maka Peneliti yang juga sebagai guru mencari alternativ lain untuk memcahkan masalah. Alternatif pilihan yang diambil adalah memilih strategi pembelajaran yang bisa meningkatkan hasil belajar siswa dengan menggunakan strategi pembelajaran Guided Note Taking bervariasi. Strategi ini dilaksanakan pada tindakan siklus I dan II.

Kegiatan pembelajaran siklus I peneliti sudah menerapkan strategi pembelajaran Guided Note Taking bervariasi. Selama proses pembelajaran dengan strategi Guided Note Taking berlangsung, siswa aktif dan kreatif. Siswa terlibat secara langsung sehingga bisa mengembangkan potensinya secara optimal. Terjadi interaksi aktif timbal balik antara guru dengan siswa, siswa dengan siswa. Pada saat melakukan presentasi siswa begitu antusias dan penuh tanggung jawab terhadap tugasnya. 
Tingkat keaktifan siswa dalam pengamatan selama proses pembelajaran pada siklus I meningkat dari kondisi awal rata-rata 27,33\% menjadi 42,67 pada siklus I. Dengan meningkatnya keaktifan siswa tersebut, memiliki dampak positif terhadap hasil belajar siswa pada mata pelajaran pendidikan kewarganegaraan khususnya pada topik usaha pembelaan negara. Setelah selesai kegiatan pembelajaran, peneliti melaksanakan evaluasi belajar. Hasil evaluasi belajar yang dilakukan pada siklus I diperoleh nilai hasil belajar siswa dengan rata-rata kelas 82,14 . Dari hasil nilai tersebut menunjukkan adanya kenaikan hasil belajar sebesar $12,45 \%$ dari kondisi awal yang hanya rata-rata kelas 73,04 .

Kenaikan keaktifan maupun hasil belajar siswa yang didapat dari siklus I, menurut peneliti masih perlu dinaikkan lagi supaya hasil semakin optimal. Maka peneliti melakukan tindakan selanjutnya yang merupakan satu rangkaian dalam penelitian ini. Kegiatan berikutnya adalah Tindakan Siklus II.

Pada tindakan siklus II, peneliti melakukan perubahan terhadap strategi pembelajaran Guided Note Taking bervariasi supaya siswa lebih berkompetisi dalam melakukan presentasi. Presentasi yang semula pada siklus I dengan posisi duduk yang searah, kemudian pada siklus II ini dengan seting tempat duduk berhadap-hadapan antar kelompok secara melingkar. Dengan strategi seperti ini peneliti berharap agar siswa semakin tinggi daya saing dan lebih kritis dalam melakukan presentasi. Dengan meningkatnya keaktifan diharapkan dapat meningkatkan hasil belajar.

Ternyata yang terjadi pada siklus II menjadi sebuah kenyataan yang diharapkan oleh peneliti. Terjadi peningkatan keaktifan dan hasil belajar siswa. Terbukti ketika dilakukan pengamatan keaktifan siswa mencapai 72,67\%. Meningkatnya keaktifan siswa tersebut memiliki pengaruh terhadap nilai hasil belajar siswa. Setelah diadakan penilaian akhir pelajaran hasil nilai yang diperoleh siswa kelas IXB pada siklus II ini rata-rata adalah 86,07. Jika bandingkan dengan siklus I, maka hasil nilai siswa pada siklus II ini mengalami kenaikan sebesar 4,78\%. Dengan naiknya nilai rata-rata hasil belajar siswa menunjukkan adanya kenaikan hasil belajar siswa, sehingga hasil belajar pada siklus II menjadi tinggi.

Dari uraian tersebut di atas, maka dalam pembahasan antar siklus ini dapat disimpulkan bahwa: (a)Ada kenaikan keaktifan siswa dari rata-rata kondisi awal 
27,33\% menjadi 42,67 pada siklus I, dan 72,67\% pada siklus II. Kenaikan dari kondisi awal ke siklus I naik secara signifikan sebesar 56,12\%, kemudian siklus I ke siklus II naik sebesar 70,31\%. (b) Ada kenaikan hasil belajar yang signifikan dari kondisi awal dengan rata-rata 73,04 menjadi 82,14 pada siklus I, dan 86,07 pada siklus II. Kenaikan nilai hasil belajar sebesar $12,45 \%$ dari kondisi awal ke siklus I, dan 4,78\% dari siklus I ke siklus II.

Berdasarkan data tersebut di atas, maka dapat dinyatakan bahwa pelaksanaan tindakan pada siklus I dan siklus II terdapat peningkatan keaktifan dan hasil belajar siswa yang signifikan. Dari kondisi awal keaktifan dan hasil belajar siswa kelas IXB SMP Negeri 1 Wonosegoro semester 1 tahun pelajaran 2017/2018 yang semula rendah, dapat meningkat pada siklus I, dan menjadi tinggi pada siklus II. Tingkat kemajuan atau perkembangan pembelajaran di kelas IXB pada kondisi awal, siklus I dan siklus II dapat digambarkan dengan grafik sebagai berikut:

Grafik 1.

Perbandingan Keaktifan dan Hasil Belajar Siswa pada Kondisi Awal, Siklus I dan Siklus II

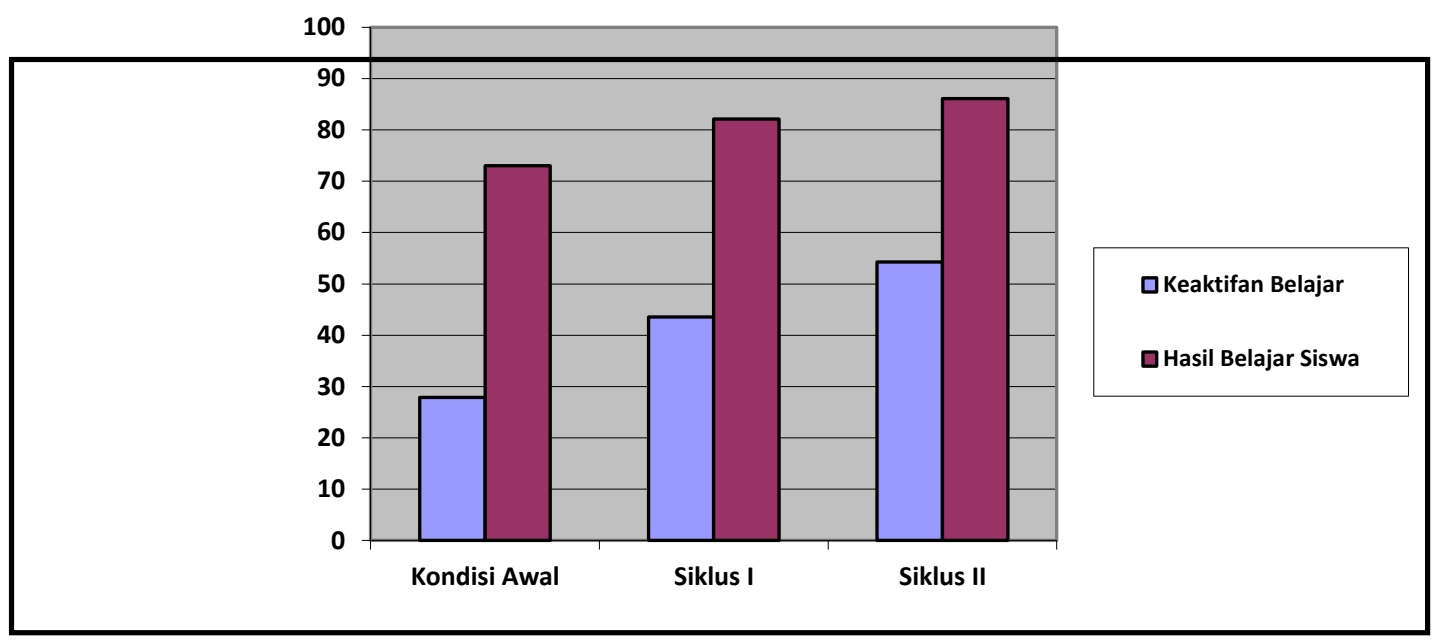

\section{SIMPULAN DAN SARAN}

Setelah diadakan analisis data dan pembahasan hasil penelitian tindakan kelas yang menerapkan strategi pembelajaran Guided Note Taking bervariasi, maka dapat disimpulkan sebagai berikut.

1. Keaktifan belajar dapat meningkat melalui penerapan strategi pembelajaran Guided 
Note Taking bervariasi pada mata pelajaran Pendidikan Kewarganegaraan topik Usaha Pembelaan Negara bagi siswa kelas IXB SMP Negeri 1 Wonosegoro semester 1 tahun pelajaran 2017/2018.

2. Hasil belajar dapat meningkat melalui penerapan strategi pembelajaran Guided Note Taking bervariasi pada mata pelajaran Pendidikan Kewarganegaraan topik Usaha Pembelaan Negara bagi siswa kelas IXB SMP Negeri 1 Wonosegoro semester 1 tahun pelajaran 2017/2018.

3. Keaktifan dan hasil belajar dapat meningkat melalui penerapan strategi pembelajaran Guided Note Taking bervariasi pada mata pelajaran Pendidikan Kewarganegaraan topik Usaha Pembelaan Negara bagi siswa kelas IXB SMP Negeri 1 Wonosegoro semester 1 tahun pelajaran 2017/2018.

Saran yang disampaikan oleh Peneliti setelah melaksanakan Penelitian tindakan kelas yang berjudul: " Peningkatkan Keaktifan Dan Hasil Belajar Melalui Penerapan Strategi Pembelajaran Guided Note Taking Bervariasi Pada Mata Pelajaran Pkn Topik Usaha Pembelaan Negara Bagi Siswa Kelas IXB SMP Negeri 1 Wonosegoro Semester 1 Tahun Pelajaran 2017/2018" ini adalah:

1. Bagi Peneliti, dapat dikembangkan untuk penelitian pada pelajaran atau materi lain yang relevan.

2. Para guru, khususnya guru Pendidikan Kewarganegaraan hendaknya memperluas wawasan model-model pembelajaran secara teoritis yang selanjutnya dapat menerapkannya dalam pembelajaran agar lebih bermakna.

3. Kepala sekolah hendaknya mengupayakan adanya pelatihan-pelatihan terhadap keprofesian guru tentang pengembangan model-model pembelajaran dan litian tindakan kelas.

4. Untuk sekolah dapat digunakan sebagai bahan pustaka atau referensi pengembangan managemen pembelajaran di sekolah. 
www.journal.univetbantara.ac.id/index.php/ijimm

\section{DAFTAR REFERENSI}

Balai Pustaka. 2005. Kamus Besar Bahasa Indonesia. Jakarta. Pusat Bahasa Departemen Pendidikan Nasional. Balai Pustaka

Diny Handayani, dan Sadiah Kusumahwati. 2009. Perencanaan Desain Pembelajaran Bahan Ajar untuk Diklat e-Training PPPPTK TK dan PLB. Pusat Pengembangan dan Pemberdayaan Pendidikan dan Tenaga Kependidikan Taman Kanak-Kanak dan Pendidikan Luar Biasa.

Elin Rosalin. 2008. Gagasan Merancang Pembelajaran Kontekstual. Bandung: PT. Karsa Mandiri Persada.

E.Mulyasa. 2009. Standar Kompetensi dan Sertifikasi Guru. Bandung: PT. Remaja Rosdakarya.

Hendy Herwawan. 2010. Teori Belajar dan Motivasi. Bandung: CV. Citra Praya.

Lukmanul Hakiim.2009. Perencanaan Pembelajaran. Bandung. CV Wacana Prima.

Margaret E. Bell Gredler, 1991: 436. Belajar dan Membelajarkan Seri Pustaka Teknologi Pendidikan No.11. Jakarta: CV. Rajawali.

Sri Hartati. 2007. Model Pembelajaran Inovatif. Semarang: Dinas Diknas.

Undang-Undang Nomor 20 Tahun 2003 Tentang Sistem Pendidikan Nasional Jakarta: Fokus Media.

Zaini, at all. 2004. Strategi Pembelajaran Aktif. Yogyakarta: CTSD (Center for Teaching Staff Development) Institut Agama Islam Negeri Sunan Kalijaga. 